\title{
Understanding the Impact of Extracellular Polymeric Substances on Lead Release in Drinking Water Systems
}

\author{
Yaohuan Gao, ${ }^{\circledR}$ Benjamin F. Trueman, Amina K. Stoddart, and Graham A. Gagnon* \\ Department of Civil \& Resource Engineering, Dalhousie University, 1360 Barrington Street, Halifax, Nova Scotia, Canada B3H 4R2 \\ Supporting Information
}

ABSTRACT: Lead release in a lead (Pb, anode)-iron oxide $(\alpha$ $\mathrm{Fe}_{2} \mathrm{O}_{3}$, cathode) galvanic system was studied under the influence of synthetic extracellular polymeric substances (sEPS). Sodium alginate, bovine serum albumin (BSA), and cytochrome c represented extracellular polysaccharides, proteins, and electrochemically active components, respectively. Microbiologically influenced corrosion was investigated using sEPS and pelleted and resuspended Pseudomonas aeruginosa cells. Relative to the anaerobic inorganic control, $\mathrm{Pb}$ release increased by 156,202 , and $198 \mu \mathrm{g} / \mathrm{L}$ when sEPS was present on the cathode side at $200 \mathrm{mg} / \mathrm{L}(100 \mathrm{mg} / \mathrm{L}$ alginate $+100 \mathrm{mg} / \mathrm{L} \mathrm{BSA}), 400$ $\mathrm{mg} / \mathrm{L}(200 \mathrm{mg} / \mathrm{L}$ alginate $+200 \mathrm{mg} / \mathrm{L} \mathrm{BSA})$, and $200 \mathrm{mg} / \mathrm{L}$ with $123.84 \mathrm{mg} / \mathrm{L}$ cytochrome $\mathrm{c}$, respectively, under anaerobic conditions. When the cathode was aerated, $\mathrm{Pb}$ release increased by 75,260 , and $-71 \mu \mathrm{g} / \mathrm{L}$ under the aforementioned conditions, all relative to the aerated inorganic control. When sEPS was instead present on the anode side, sEPS caused localized corrosion on $\mathrm{Pb}$ and resulted in higher $\mathrm{Pb}$ release than predicted by electric current. $P$. aeruginosa generally enhanced corrosion; when cells were dosed in the anode side, part of the oxidized $\mathrm{Pb}$ was immobilized by cells or organic compounds adhered to the electrodes.

\section{INTRODUCTION}

Environmental lead exposure is strongly linked to cognitive deficits in children ${ }^{1}$ and cardiovascular disease mortality in adults. ${ }^{2}$ While exposure has declined dramatically over the past 50 years due to public health interventions, ${ }^{3}$ tap water remains an important mode of exposure. ${ }^{4}$ Significant sources of lead in this context include legacy lead pipes, leaded solder, leaded brass, and galvanized steel pipe. ${ }^{5}$

Lead release to drinking water is a complex and dynamic process influenced by water chemistry variables, such as disinfectant type, ${ }^{6}$ the availability of orthophosphate or other corrosion inhibitors, ${ }^{7}$ the concentration of corrosive anions, ${ }^{8}$ and the composition of natural organic matter (NOM)..$^{7 a}$ Additionally, galvanic lead corrosion is a significant cause of elevated lead levels in drinking water. ${ }^{8 a, 9}$ Galvanic reactions between lead and other metals, including copper-brass following partial lead service line replacement, have been reported. ${ }^{10,117 b, 9,10}$ Corrosion products may also induce galvanic corrosion: one possibility is galvanic interaction between colloidal/particulate iron oxides and the surfaces of lead service lines. These reactions might be prevalent in systems with both lead service lines and corroded upstream iron mains. ${ }^{12}$

Microbiologically influenced corrosion (MIC) is often an important corrosion pathway of iron $^{13}$ and copper ${ }^{14}$ pipelines, but biofilm has received comparatively little attention as a driver of lead release from lead service lines. ${ }^{13,15}$ In one study of biofilm in lead service lines, bacteria from multiple genera

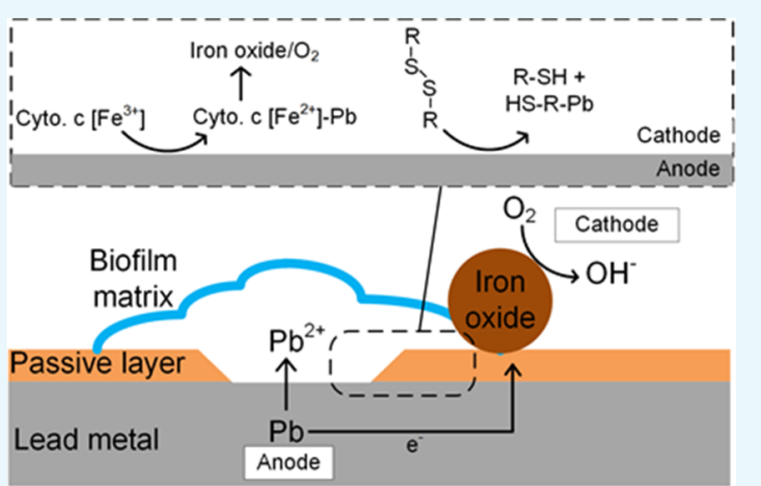

such as Massilia, Bacillus, Sphingomonas, Arthrobacter, Brevundimonas, Microbacterium, Paenibacillus, and Exiguobacterium were detected, and these bacteria are either heavy metal tolerant or capable of surviving in heavy-metal-rich environment; ${ }^{15 \mathrm{~b}}$ an earlier study of lead pipes recovered from the city of Rochester in NY simply reported the detection of coliform bacteria in the scales. ${ }^{16}$ Generally, biofilms in drinking water distribution systems may induce biological corrosion and harbor opportunistic human pathogens such as Legionella pneumophila, Mycobacterium avium, and Pseudomonas aeruginosa. ${ }^{17}$ During the Flint water crisis, interruption of corrosion control accompanied the occurrence of Legionella at points of use within the system. ${ }^{18}$ These observations suggest that corrosion may promote biofilm growth by depleting disinfectant residuals, and biofilm can in turn influence corrosion by altering the localized conditions at the metalwater interface.

Conventional studies of MIC often focus on microbial metabolisms such as $[\mathrm{H}]$ consumption and $\mathrm{H}_{2} \mathrm{~S}$ generation by sulfate-reducing bacteria. ${ }^{19}$ However, biofilms are largely composed of extracellular polymeric substances (EPS), including polysaccharides, proteins, lipids, and nucleic acids. $^{20}$ EPS can substantially exceed cell volume in drinking water distribution systems. ${ }^{20 a}$ At the interface of metallic pipe/

Received: September 12, 2018

Accepted: October 26, 2018

Published: November 5, 2018 


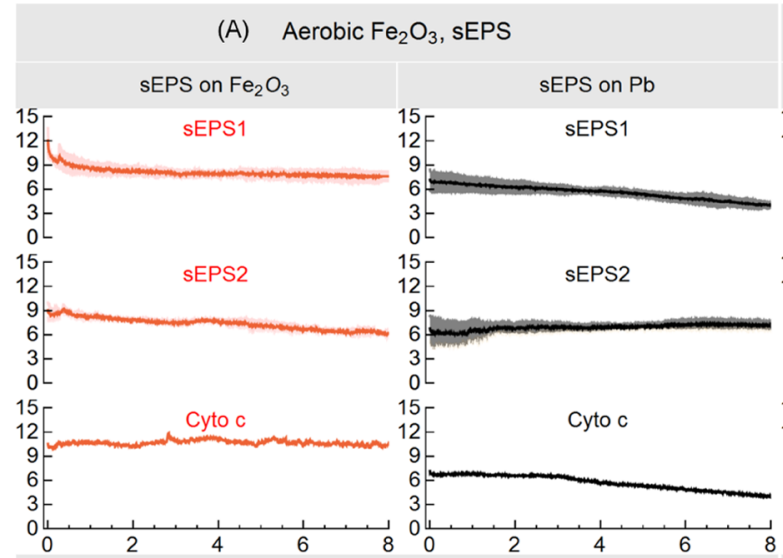

(C) Anaerobic $\mathrm{Fe}_{2} \mathrm{O}_{3}$, sEPS

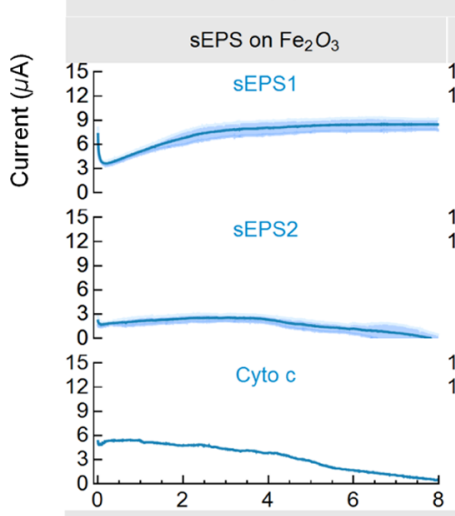

(E) Inorganic control tests
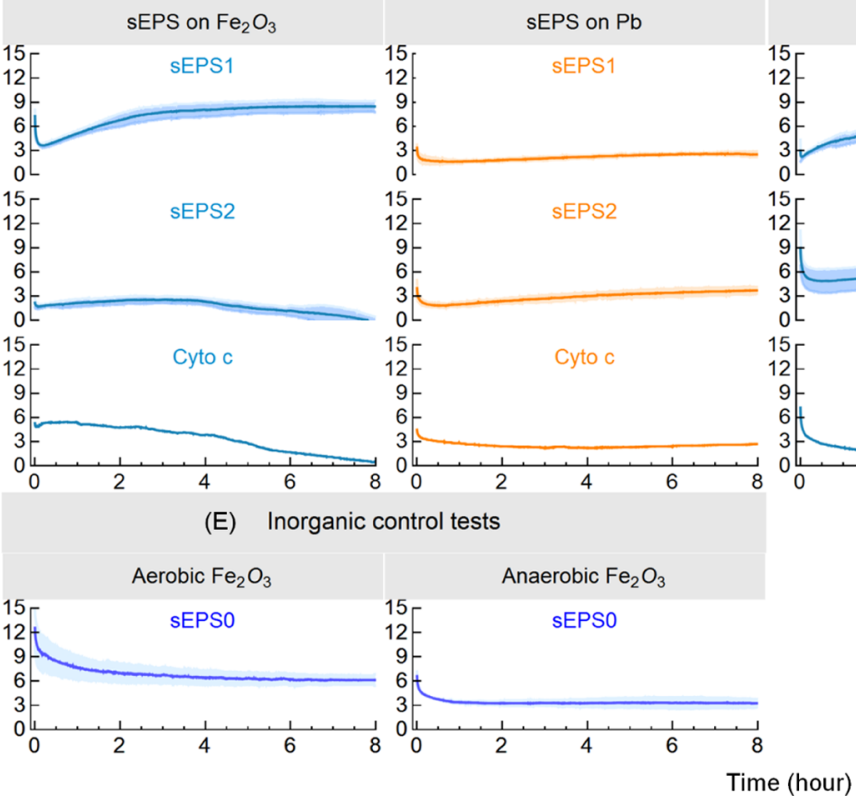

(B) Aerobic $\mathrm{Fe}_{2} \mathrm{O}_{3}, \mathrm{sEPS}+$ cells

sEPS on $\mathrm{Fe}_{2} \mathrm{O}_{3}$

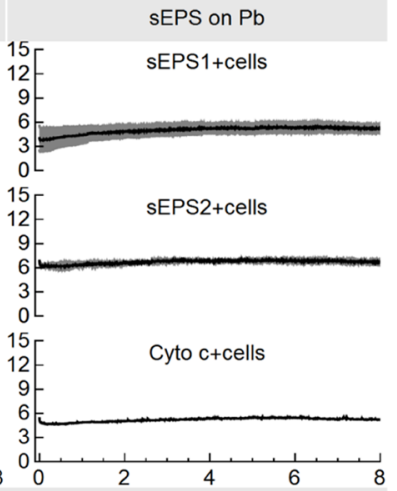

(D) Anaerobic $\mathrm{Fe}_{2} \mathrm{O}_{3}$, sEPS+cells

sEPS on $\mathrm{Fe}_{2} \mathrm{O}_{3}$

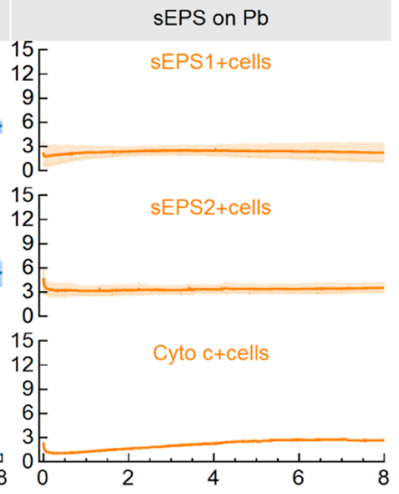

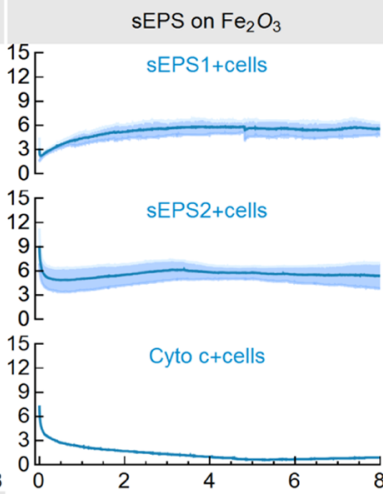




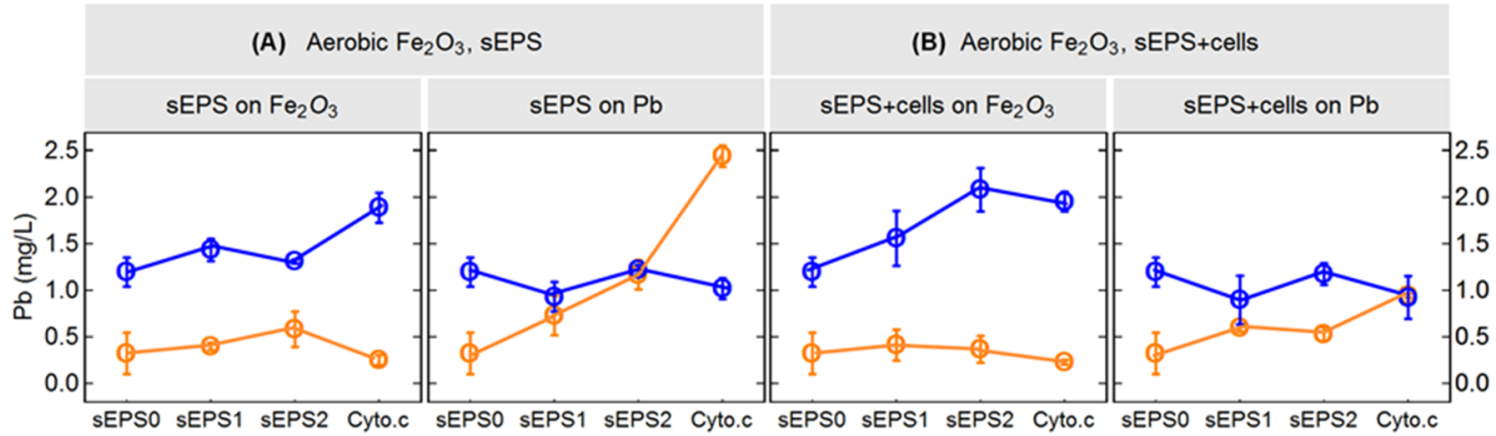

(C) Anaerobic $\mathrm{Fe}_{2} \mathrm{O}_{3}$, sEPS

(D) Anaerobic $\mathrm{Fe}_{2} \mathrm{O}_{3}$, sEPS+cells

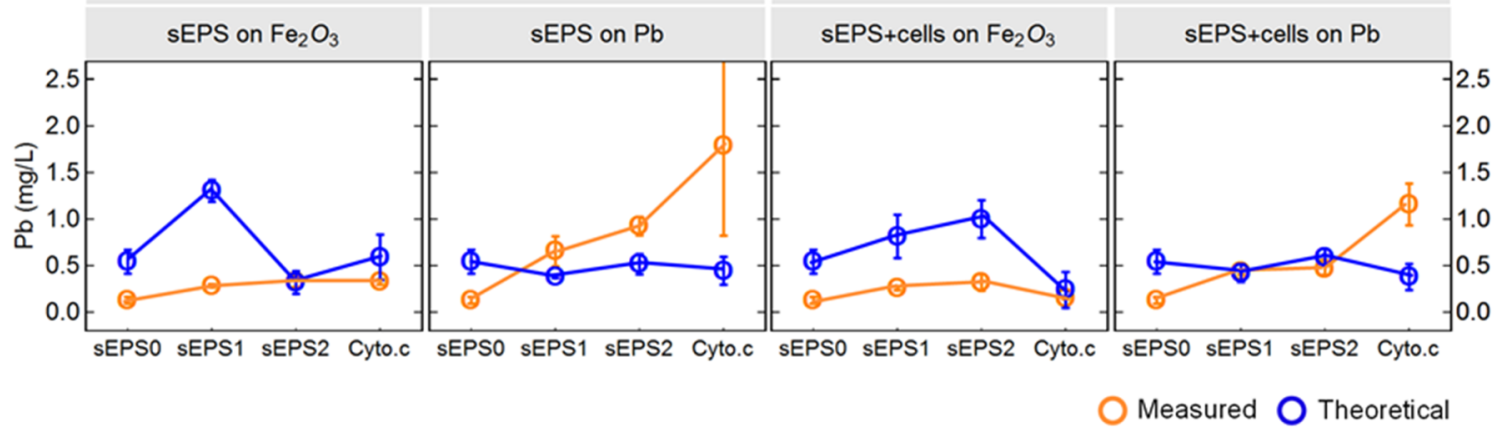

Figure 2. Measured aqueous lead concentrations (orange) and theoretically oxidized lead concentrations (blue) from all the tested conditions. Panels (A) and (C) show the lead concentrations with only sEPS in the system; panels (B) and (D) show the lead concentrations in the presence of $P$. aeruginosa cells. Rings and error bars represent the means and one standard deviation from the means, respectively.

anaerobic conditions. The same ANOVA showed significant interaction of sEPS and DO (Figure S2-A1; sEPS on $\mathrm{Fe}_{2} \mathrm{O}_{3}$ : $\left.F_{2,15}=20.00, p<0.0001\right)$, whereas an analysis based on measured lead concentrations showed insignificant interaction (Figure S2-A1; sEPS on $\mathrm{Fe}_{2} \mathrm{O}_{3}: F_{2,14}=0.42, p>0.05$ ). Thus, the selected levels of sEPS may have affected oxygen diffusion, as described in the next paragraph. Only a fraction of the oxidized lead was recovered from the aqueous phase at $\mathrm{pH}$ 7.5-8.5 (Figure 2A,B: sEPS on $\mathrm{Fe}_{2} \mathrm{O}_{3}$ ), presumably due to the formation of lead carbonate compounds on lead coupon surfaces. $^{7 \mathrm{a}}$ For this reason, electric current more accurately estimates total oxidized lead (blue rings in Figure 2) as compared with total detected aqueous lead (orange rings in Figure 2) in the absence of localized corrosion at the anode.

Previous studies on the effect of EPS on the corrosion of iron or steel often report divergent findings: both corrosion induction and inhibition by EPS have been documented. ${ }^{24}$ Corrosion induced by EPS is usually attributed to (1) the formation of a differential aeration cell caused by the uneven distribution of EPS on metal surfaces and (2) encouraged anodic reaction via complexation of oxidized iron. The passivation caused by EPS is often explained by (1) the reduced diffusivity of DO in a viscous organic matrix and (2) stabilization of corrosion products. ${ }^{25}$ In this study, lead oxidation was not proportional to the concentration of sEPS under aerobic conditions. This may be explained by restricted diffusion of oxygen at the higher level of sEPS. Observations under anaerobic conditions may be explained by two other interacting processes: reduction of BSA and restricted diffusion of reduced iron species. The measured potential of the cathode in the presence of sEPS1 was between -0.47 and $-0.73 \mathrm{~V}$ (Figure S3). This overlaps with the potential range for the reduction of disulfide bonds from BSA, -0.45 to $-0.65 \mathrm{~V}$, indicating possible breakage of the disulfide bonds on the cathode. The negative current upon contact of sEPS2 with iron oxide during a hematite-hematite galvanic test supports this speculation (Figure 3): the side dosed with sEPS2 accepted electrons from the other side. Although BSA is different from microbial extracellular proteins, disulfide bonds may be prevalent in EPS. Proteins are known to form disulfide bonds through the oxidation of cysteine thiols under the oxidative stress of chlorine species, ${ }^{27}$ which are common in water distribution systems. In the presence of sEPS2, the reduction of disulfide bonds was still likely, but binding and accumulation of reduced iron on the cathode surfaces at higher viscosity may have caused an early termination of the cathodic reaction.

Polymeric Substances on the Anode Side. sEPS on the anode significantly affected theoretically oxidized lead, but to a lesser extent than in the corresponding cathode experiments (Figure S2-A1; sEPS on Pb: $F_{2,14}=7.14, p<0.005$ ). When the average theoretically oxidized lead concentrations of the tested conditions and the corresponding control conditions were compared, sEPS 1 depressed corrosion by 22 and $29 \%$ under aerobic and anaerobic conditions, respectively; sEPS2 had little effect (Figures 1A,C,E and 2A,C: sEPS on Pb). However, some of the measured aqueous lead concentrations were higher than the theoretical values (Figure 2A,C: sEPS on $\mathrm{Pb}$ ). For example, the measured lead concentrations, $0.82-1.01 \mathrm{mg} / \mathrm{L}$, were approximately twice the theoretical lead level, $0.40-0.62 \mathrm{mg} /$ $\mathrm{L}$, when the cathode was in an anaerobic condition and sEPS2 contacted the anode. This discrepancy suggests the occurrence of localized or non-galvanic corrosion. In a previous work, lead concentrations in excess of predictions based on galvanic current were observed and attributed to localized non-galvanic corrosion. ${ }^{28}$ In the presence of free chlorine under continuous flow, the excess lead concentrations that were observed by the authors may be attributed to redox reaction between $\mathrm{PbO}_{2}$, a 
corrosion product, and lead metal. In another study, extracellular polysaccharides from sulfate-reducing bacteria were hypothesized to be responsible for the localized oxidation of steel, ${ }^{2 \mathrm{~b}}$ although bacterial extracellular polysaccharides are rarely reported as redox active unless they bind redox-active ions, such as $\mathrm{Fe}^{3+}$ or $\mathrm{U}^{6+} \cdot{ }^{29}$ Since the lead coupons in this study were acid-washed and alginate is inert to common electron transfer reactions involving metals and metal oxides, ${ }^{30}$ the much-higher lead recovery indicates that a distinct nongalvanic corrosion occurred. Size-exclusion chromatography and inductively coupled plasma mass spectrometry (SEC ICPMS) chromatograms (Figure 4) show that alginate was the major complexing agent of lead in the sEPS mixture of alginate and BSA. Considering the oxidative property of BSA, the observed non-galvanic reaction could stem from the reduction of BSA and the complexation of ionized lead by alginate. Whether the two reactions occurred simultaneously or sequentially is unknown, but the lead-lead galvanic test suggests that the sEPS demonstrate a strong ability to bind or withdraw $\mathrm{Pb}^{2+}$ from the anode surfaces as opposed to accepting electrons from the anode (Figure 3)-electrons flowed away from the lead electrode that was in contact with sEPS2, indicating the generation of excessive electrons on that electrode through complexation of lead.
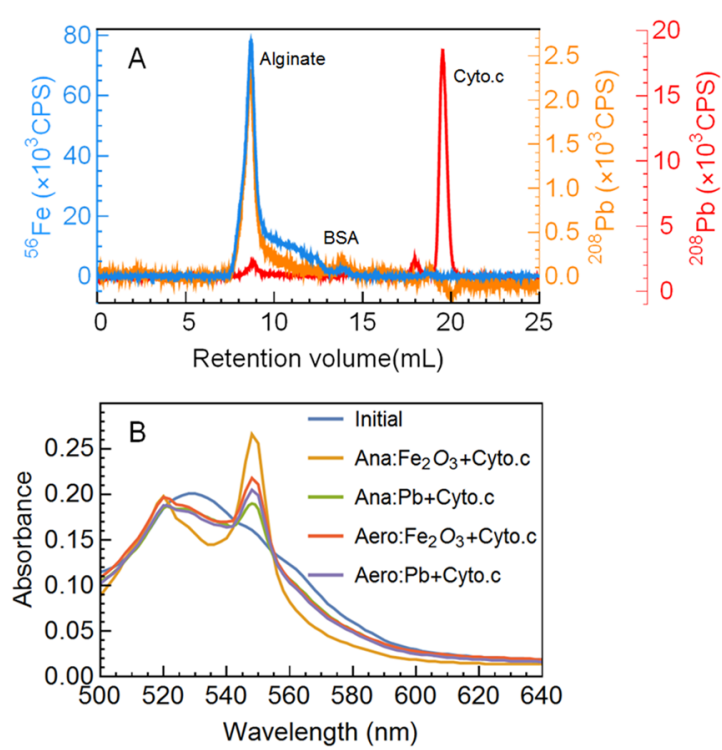

Figure 3. Representative chromatograms and UV-vis absorption spectra showing the complexation of metal ions and reduction of cytochrome c. Panel (A) shows the complexation of Pb by sEPS1 (alginate and BSA) on the anode (orange), the complexation of Fe by sEPS1 on the cathode (blue), and the complexation of $\mathrm{Pb}$ when Cyto. c (alginate, BSA, and cytochrome c) was on the anode (red). Panel (B) shows the contrast of UV-vis absorption spectra from cytochrome $c$ before and after corrosion tests on the anode and cathode in which anaerobic or aerobic states the condition on the cathode side and those after the colon indicate the location of Cyto. c.

Effect of Dissolved Oxygen. When the corrosion under aerobic and anaerobic conditions is compared in terms of the theoretically oxidized lead, the effect of DO was positive and statistically significant (Figures 2A,C and $\mathrm{S} 2$ : sEPS on $\mathrm{Fe}_{2} \mathrm{O}_{3}$, $F_{1,15}=124.21, p<0.0001$ and sEPS on $\mathrm{Pb}, F_{1,14}=156.60, p<$ $0.0001)$. An ANOVA on measured aqueous lead concentrations reached the same conclusion. For instance, when the sEPS contacted the cathode, the aerobic condition yielded oxidized lead ranging from 0.36 to $0.74 \mathrm{mg} / \mathrm{L}$, while the anaerobic condition generated $0.27-0.40 \mathrm{mg} / \mathrm{L}$ lead. The measured potential of the cathode was approximately $-0.47 \mathrm{~V}$ with DO and declined to approximately $-0.66 \mathrm{~V}$ under anaerobic conditions, bringing a dramatic drop, from 0.28 to $0.09 \mathrm{~V}$, in the driving force of the galvanic corrosion (Figure S3). Oxygen is one of the main electron acceptors in the corrosion of metallic piping materials. ${ }^{21}$ In this study, DO reduction was expected on the cathode surfaces by electrons originating from lead oxidation. The stepwise transfer of electrons from lead to iron oxide and finally to oxygen is in line with the electron-conducting activity of iron-sulfur compounds in sulfate-induced iron corrosion, as both iron compounds are semiconductive. ${ }^{31}$

Galvanic Corrosion in the Presence of P. aeruginosa. P. aeruginosa was employed to investigate corrosion with cell adhesion on the electrodes. The duration of tests here allows cell adhesion, which often requires $20-40 \mathrm{~min},{ }^{32}$ but is short enough that biofilm formation via the consumption of sEPS was minimized. ${ }^{33}$ When bacterial cells were dosed with sEPS (Figure 1B,D), the interaction between sEPS and DO was not significant in ANOVA with either predicted or observed lead release as the response (Figure S2-A2). The main effects of DO and sEPS on lead corrosion were significant, except in the ANOVA with measured lead concentrations and sEPS on the cathode (DO: $F_{1,13}=4.02, p>0.05$; sEPS: $F_{2,13}=1.82, p>$ 0.1 ). Here as well, theoretically oxidized lead was considered a better metric of galvanic reactions. Cell lysis occurred during the test: the optical density at $600 \mathrm{~nm}$ (OD600) of the cell suspensions before and after the tests showed decreased cell density at the end (average $2 \times 10^{8} \mathrm{CFU} / \mathrm{mL}$ ), while soluble chemical oxygen demand (sCOD) measurement showed 51$119 \%$ increase in soluble organics. The released intracellular compounds during cell lysis, an essential part of natural EPS, may have affected the corrosion process.

Generally, corrosion current in the presence of $P$. aeruginosa was slightly higher and more sustained as compared against tests without the bacterium (Figure 1). When P. aeruginosa cells were on the cathode, theoretical lead oxidation was significantly increased in both aerobic and anaerobic conditions (10-220\% increase, Figure 2). Hence, certain intracellular materials, including ions and small molecules, might have facilitated (1) the transfer of electrons on the cathode surfaces to DO or other oxidative compounds and/or (2) the diffusion of reduced iron away from the cathode. When $P$. aeruginosa cells were on the anode, the corrosion current was similar to those cases when there were no cells; however, the detected aqueous lead concentrations were lower than those cases when cells were absent (sEPS on $\mathrm{Pb}$ in Figure 2B,D compared with sEPS on $\mathrm{Pb}$ in Figure 2A,C). This was not expected because the $\mathrm{pH}$ slightly shifted to the acidic range $(7.2-7.6)$ at the end of test runs, and the decreased $\mathrm{pH}$ encourages lead dissolution. This discrepancy implies that more lead ions were immobilized on the anode via complexation with organic compounds/cells adsorbed on the anode. Nevertheless, a conclusion that sessile $P$. aeruginosa on lead surfaces is capable of impeding lead corrosion and release may not be valid because the $P$. aeruginosa in this study was not expected to have formed a mature biofilm on the anode. In an active biofilm-covered corrosion site, various other proteins or enzyme cofactors can potentially affect the reaction, and some of them are redox active around the potentials that are relevant to corrosion. Some have been demonstrated to conduct 
electrons in extracellular spaces, such as extracellular redoxactive iron-sulfur proteins ${ }^{34}$ and extracellular flavins/riboflavins. ${ }^{35}$ These observations warrant more studies on the interaction between EPS and cells in lead corrosion.

Effects of Electrochemically Active Small-Sized Proteins. Microorganisms secrete electrochemically active molecules during extracellular respiration on insoluble electron acceptors such as iron oxides and manganese dioxide. ${ }^{36}$ These oxidized forms of metals are commonly found in the corrosion scales inside lead service pipelines. ${ }^{37}$ Therefore, local biofilmcovered anaerobic spots on lead service lines may encourage the growth of microorganisms that are actively involved in the reductive dissolution of oxidized iron, manganese, or even lead. Furthermore, direct oxidation of reduced metal-metal ions by some lithoautotrophic and acetogenic microorganisms has been reported, ${ }^{38}$ and these reactions may also occur in drinking water distribution systems. Hence, it is worthwhile to examine the roles of electrochemically active molecules during corrosion processes. Cytochrome c, mobile in EPS or associated with cytoplasmic membranes, is widely reported as the reducing/oxidizing equivalent during microorganismmetal oxide redox reactions ${ }^{38,39}$ and was chosen here as a model molecule.

Effects of Cytochrome $\mathrm{c}$ on the Cathode. With Cyto. $\mathrm{c}$ on the cathode, three-way ANOVA of theoretically oxidized lead on DO, cytochrome c, and cells showed that (1) the interaction between $\mathrm{DO}$ and cytochrome $\mathrm{c}$ was significant (Figure S2-B1, $F_{1,13}=47.24, p<0.0001$ ) and (2) the interaction between DO and cells was also significant (Figure S2-B1, $F_{1,13}=10.82, p<0.01$ ). Except for DO (Figure S2-B1, $\left.F_{1,13}=114.85, p<0.0001\right)$, the main effects of the two other factors were not significant, suggesting that in the presence of cytochrome c, availability of oxygen to the cathode is crucial. The effect of DO on current is noticeable: with the cathode aerated, the current was high and sustained ranging from 10 to $12 \mu \mathrm{A}$; with the cathode de-aerated, the current gradually diminished (Figure 1). The same ANOVA with aqueous lead concentrations as the response showed that the interaction between DO and cytochrome $c$ was significant $\left(F_{1,13}=4.78, p\right.$ $<0.05)$; the main effects of DO and cytochrome c were also significant. In addition, a hematite-hematite galvanic test showed that cytochrome c, without oxygen, cannot ennoble iron oxide (Figure 3). The UV-vis absorption spectra show peaks near 520 and $550 \mathrm{~nm}$ emerging after the reaction of cytochrome $c$ on the cathode (Figure 4B), implying the reduction of cytochrome $c^{40}$ This evidence leads to the conclusions that during these corrosion tests (1) cytochrome c can be oxidized by DO and (2) cytochrome c may have mediated electron transfer from a more reduced cathode to DO and thus facilitated the oxidation of the cathode by DO. Moreover, the SEC ICP-MS chromatograms (Figure 4A) indicate that cytochrome $\mathrm{c}$ dramatically alters the apparent molecular weight distribution of lead. Although present at a low level, cytochrome c may be better able to complex with lead compared to alginate, perhaps due to its relatively small size (12000 Daltons). Thus, it is reasonable to assume that cytochrome c may have also complexed ferrous ions, assisting the cathode to revert to the oxidized condition.

Effects of Cytochrome $c$ on the Anode. With Cyto. c on the anode, a three-way ANOVA of theoretically oxidized lead on DO, cytochrome c, and cells showed that all the interactions were not significant and only the main effect of DO (Figure S2-B2, $F_{1,13}=58.08, p<0.0001$ ) was significant.

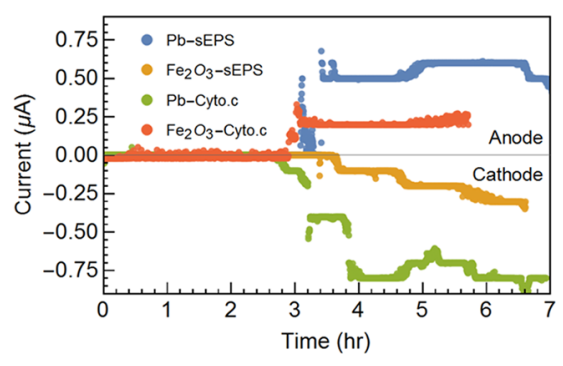

Figure 4. Lead-lead or hematite-hematite galvanic systems with sEPS and cytochrome $c$ under anaerobic conditions. Electric current usually deviates from the equilibrium value (i.e., zero) after the addition of organic compounds at the $3 \mathrm{~h}$ mark. All organic compounds were dosed to the side connected to the common (COM) port of a multimeter. The gray color line indicates zero current. Positive current indicates the expulsion of electrons from the side with organic compounds (behaves as an anode), while negative current indicates the acceptance of electrons by the electrode contacting organic compounds (behaves as a cathode).

In contrast, ANOVA with measured lead concentrations as the response showed that the interaction between cytochrome $c$ and cells was significant (Figure S2-B2, $F_{1,13}=8.65, p<0.05$ ) and the main effects of cytochrome $c\left(F_{1,13}=42.23, p<\right.$ $0.0001)$ and cells $\left(F_{1,13}=12.99, p<0.001\right)$ were also significant. When the cathode was under anaerobic condition, the corrosion current in the presence of cytochrome $c$ generally fell in the low range, below $3 \mu \mathrm{A}$, as evident from Figure 1 (sEPS on $\mathrm{Pb}, \mathrm{C} \& \mathrm{D})$. However, the detected aqueous lead levels were high, in the range of $1-2.5 \mathrm{mg} / \mathrm{L}$, and exceeded the predicted levels from corrosion current. These observations indicate that (1) galvanic current cannot reveal the effect of cytochrome $\mathrm{c}$ and its interaction with $\mathrm{DO} /$ cells on the anode and (2) when cytochrome $c$ is in contact with lead, it encourages non-galvanic corrosion. The lead-lead galvanic test with cytochrome $\mathrm{c}$ supports the idea that cytochrome $\mathrm{c}$ can accept electrons from lead (Figure 3). Although an environmental biofilm actively conducting dissimilatory metal oxide reduction usually contains a fraction of oxidized cytochrome $\mathrm{c}^{41}$ microorganisms involved in a corrosion reaction may directly oxidize metal surfaces with the assistance of oxidized cytochrome c. ${ }^{13 b, 31 c, 38,42}$ Together with its leadbinding ability (Figure 4A), the current work suggests that electrochemically active proteins, such as cytochrome $c$, may result in localized non-galvanic corrosion of lead. ${ }^{42}$

While a system that is composed of model compounds is less complex than natural biofilm matrices, the results presented here nevertheless imply that biofilm EPS may participate in the corrosion process of lead-based materials. This can happen via complexation of metal ions as well as redox reactions with corrosion products or metal surfaces. These implications, especially the latter, accord with findings from recent microbial corrosion and bioelectrochemical studies. Despite the wellaccepted hypothesis of cathodic depolarization or $[\mathrm{H}] / \mathrm{H}_{2}$ utilization during the sulfate-driven MIC, direct electron transfer from metal atoms to bacteria through iron and iron-sulfur compounds may occur. ${ }^{31}$ These studies showed that sulfate-reducing and methane-generating microorganisms directly extracted electrons from the surfaces of metals or corrosion products. This direct electron transfer might have relied on either cytoplasmic membrane-associated or extracellular cytochrome c. ${ }^{39}$ In another case, extracellular hydrogenase or formate dehydrogenase from Methanococcus 
Table 1. Experimental Design of the Lead-Iron Oxide Galvanic Corrosion ${ }^{a}$

\begin{tabular}{|c|c|c|}
\hline & cathode $\left(\mathrm{Fe}_{2} \mathrm{O}_{3}\right)$ & anode $(\mathrm{Pb})$ \\
\hline \multirow[t]{2}{*}{ control tests* (inorganic controls) } & anaerobic & anaerobic \\
\hline & aerobic & anaerobic \\
\hline \multirow[t]{4}{*}{ tests on sEPS* } & anaerobic + sEPS1, sEPS2, or Cyto. $c^{\#}$ & anaerobic \\
\hline & aerobic + sEPS1, sEPS2, or Cyto. $c^{\#}$ & anaerobic \\
\hline & anaerobic & anaerobic + sEPS1, sEPS2, or Cyto. $c^{\#}$ \\
\hline & aerobic & anaerobic + sEPS1, sEPS2, or Cyto. $c^{\#}$ \\
\hline \multirow[t]{4}{*}{ tests on sEPS in the presence of bacterial cells* } & anaerobic + sEPS1, sEPS2, or Cyto. $c^{\#}$ & anaerobic \\
\hline & aerobic + sEPS1, sEPS2, or Cyto. $c^{\#}$ & anaerobic \\
\hline & anaerobic & anaerobic + sEPS1, sEPS2, or Cyto. $c^{\#}$ \\
\hline & aerobic & anaerobic + sEPS1, sEPS2, or Cyto. $c^{\#}$ \\
\hline
\end{tabular}

maripaludis catalyzed the formation of $\mathrm{H}_{2}$ or formate on iron surfaces in the absence of cells, and the formation of these reducing equivalents was well correlated to the corrosion process. ${ }^{13 \mathrm{~b}}$ Additionally, biofilms may trap and accumulate trace amounts of NOM containing redox-active functional groups that resemble quinones; ${ }^{43}$ some of these are still oxidative following disinfection ${ }^{44}$ and may act as an electron sink in a corrosion reaction. Therefore, during MIC of lead pipelines, commonly observed binding or complexing of metal ions ${ }^{21,24}$ probably takes place in concert with redox reactions between redox-active molecules in EPS and the solid surfaces, especially in a local anaerobic environment away from the bulk liquid. These reactions are relatively independent of traditionally reported galvanic reactions and may significantly influence the dynamics of lead corrosion and release. Future studies on the corrosion of lead pipes at pilot- or full-scale could be designed to address some of the limitations of this study. In particular, the role of biofilm under more representative drinking water conditions that include elements related to a well-developed corrosion scale, corrosion control agent, and a disinfectant residual should be examined. In this way, the synergies observed here between EPS and lead release can have greater application context.

\section{MATERIALS AND METHODS}

Experimental Design. Scanning electron microscopy images from previous studies 9,45 show that the corrosion scales on lead service lines are often porous, especially when a phosphate corrosion inhibitor is applied. The interstitial space covered by biofilm in lead service line corrosion scales may develop oxygen-rich and oxygen-depleted zones. Therefore, the corrosion of lead was examined when the cathode side was in one of two extreme DO conditions, aerobic or anaerobic, while the anode was always maintained in an anaerobic condition. Sodium alginate and bovine serum albumin (BSA) were employed as models for polysaccharides and proteins in EPS, respectively; cytochrome $\mathrm{c}$ was used to represent electrochemically active small-sized proteins in EPS. ${ }^{46}$ These model compounds were added to either the anode chamber or the cathode chamber to study their influence on the corrosion process. Two groups of tests with sEPS were studied as shown in Table 1 ; the first group only involved sEPS, while the second group incorporated planktonic bacterial cells in the system. Within each group, three different sEPS conditions were examined: $100 \mathrm{mg} / \mathrm{L}$ alginate $+100 \mathrm{mg} / \mathrm{L}$ BSA (labeled sEPS1); $200 \mathrm{mg} / \mathrm{L}$ alginate $+200 \mathrm{mg} / \mathrm{L} \mathrm{BSA}$ (labeled sEPS2); and $100 \mathrm{mg} / \mathrm{L}$ alginate $+100 \mathrm{mg} / \mathrm{L} \mathrm{BSA}+123.84 \mathrm{mg} / \mathrm{L}$ cytochrome c (C7752, Sigma-Aldrich) (labeled Cyto. c).
These concentrations were chosen to simulate the concentrations of EPS in biofilm or at the biofilm and water interface. ${ }^{47}$ Since heavy-metal-resistant microorganisms mostly inhabit copper and lead pipelines, ${ }^{15 b, 43,47}$ the lower end of a commonly studied EPS concentration range (a few hundreds to $10000 \mathrm{mg} / \mathrm{L})^{13 \mathrm{a}, 22 \mathrm{~b}, \mathrm{c}}$ was selected. The concentration of cytochrome $\mathrm{c}$ was determined according to a previous study on Geobacter spp. ${ }^{48}$ Microorganisms have been shown to occur both on top and beneath corrosion scales and to induce pitting corrosion in copper and iron pipelines. ${ }^{13 c, 14 b}$ Since MIC in lead corrosion has rarely been reported, ${ }^{15 b, 16}$ MIC of copper was deemed analogous to MIC of lead. Therefore, bare lead coupons were applied in this preliminary study of the effect of sEPS on lead corrosion; corrosion scale was allowed to develop over the $8 \mathrm{~h}$ test period. The control tests in the base electrolyte with either aerobic cathode or anaerobic cathode were labeled sEPSO (i.e., no sEPS), and the tests carried out with bacterial cells were denoted XX + cells.

Two-way ANOVA was conducted to compare the main effects of DO (anaerobic and aerobic) and sEPS (sEPSO, sEPS1, and sEPS2) and the interaction effect between DO and sEPS on galvanic corrosion. In the presence of cytochrome $c$ and cells, three-way ANOVA was applied to examine the main effects of DO (anaerobic and aerobic), cytochrome c (sEPS1 and Cyto. c), and bacterial cells (with and without cells) plus the interactions among these three factors; all tests were conducted at a significance level of 0.05 . Two sets of data were analyzed by ANOVA: the measured total aqueous lead concentrations and the theoretical lead release as predicted by Faraday's law from galvanic current (eq 1). Wolfram Mathematica 11.3 was used for comparisons and for figure preparation.

$$
C=\frac{M \times \int I \mathrm{~d} t}{z \times F \times V}
$$

where $C$ is the equivalent (or theoretical total released) lead concentration in $\mathrm{g} / \mathrm{L} ; M$ is the molar mass of lead, $207.2 \mathrm{~g} /$ mol; $I$ is current in Ampere; $t$ is the elapsed time in second; $z$ is the charges of lead ions, which is 2 here; $F$ is the Faraday constant, $96485 \mathrm{C} / \mathrm{mol}$; and $V$ is the volume of the base electrolyte in each chamber, $0.175 \mathrm{~L}$.

Galvanic Cells. A double-chamber electrochemical reactor (Figure S1) was used in this study. Spark plasma sintered $\alpha$ $\mathrm{Fe}_{2} \mathrm{O}_{3}$ disks ${ }^{7 \mathrm{a}}$ and lead coupons (Ames Metal Products Co.) served as the cathode and anode, respectively. For each test run, a pair comprising one $\mathrm{Fe}_{2} \mathrm{O}_{3}$ disk and one lead coupon was randomly selected from four identical $\mathrm{Fe}_{2} \mathrm{O}_{3}$ disks and 
three identical lead coupons. The half-cells $(250 \mathrm{~mL} / \mathrm{side})$ were each made from a media bottle, and they were connected via a salt bridge $(2.5 \%$ of agar and $3 \mathrm{~mol} / \mathrm{L} \mathrm{KCl})$. The body of the salt bridge was a $32.5 \mathrm{~cm}$-long MasterFlex \#16 silicone tube. The electrode and the external measurement circuit were connected using an alligator clip and titanium wires (0.051 in. diameter, McMaster Carr). The base electrolyte $(\mathrm{pH} \geq 7.5)$ was $60 \mathrm{mg} / \mathrm{L}$ sodium bicarbonate in ultrapure water; the $\mathrm{pH}$ in the anode chamber increased after test runs but was always below 8.5 , while the $\mathrm{pH}$ in the cathode chamber varied little. When cells were present in the electrolyte, the $\mathrm{pH}$ at the end of the reactions was in the range of 7.2-7.6. Two extra lines made of MasterFlex \#14 pump tubing were added to allow gas exchange. Nitrogen sparging (Air Liquide, $2 \mathrm{~L} / \mathrm{min}, \geq 30 \mathrm{~min}$ ) was applied to create the anaerobic condition. The corrosion current was recorded by a digital multimeter (PeakMeter MS8236). Electrode potentials were measured against $\mathrm{Ag} /$ $\mathrm{AgCl}$ electrodes (BME $8 \mathrm{~W}$, BioMed Products Inc), and details are available in the Supporting Information (Figure S3). Fresh stock solutions of sEPS $(100 \times$ concentrated) were prepared every 2 weeks and stored at $4{ }^{\circ} \mathrm{C}$. Before a test run, the sEPS were added by mixing the stock solutions with the base electrolyte. Flakes of cytochrome $\mathrm{c}$ were dissolved in the base electrolyte when needed. Thin films of polymeric substances were allowed to form through the partitioning of sEPS components between the liquid and solid phases. As a control, the effect of chloride on galvanic corrosion was also evaluated (Figure S4).

To oxidize the reduced portion of the $\mathrm{Fe}_{2} \mathrm{O}_{3}$ disks after each test, the disks were thoroughly rinsed with water, dried at 102 ${ }^{\circ} \mathrm{C}$, and then baked at $750{ }^{\circ} \mathrm{C}$ for $3 \mathrm{~h} .{ }^{49}$ Lead coupons were immersed in dilute nitric acid for $10 \mathrm{~min}$ and then rinsed with ultrapure water before each test. Lead is known not to form corrosion scales in dilute nitric acid. ${ }^{50}$ When necessary, the coupons were polished with 320-grit sandpaper. After each test, the electrodes were removed from the solutions, and $4 \mathrm{~mL}$ of trace-metal-grade nitric acid was added to desorb lead from the glass bottle surfaces; the bottles were sealed and stored at 4 ${ }^{\circ} \mathrm{C}$ for at least $24 \mathrm{~h}$ before analysis. When sEPS were present, nitric acid digestion $\left(2 \mathrm{~mL} \mathrm{HNO}_{3}+2 \mathrm{~mL} 30 \% \mathrm{H}_{2} \mathrm{O}_{2}+15 \mathrm{~mL}\right.$ sample, $105{ }^{\circ} \mathrm{C}$ and $2 \mathrm{~h}$ ) was applied to disintegrate the alginate flocs. For electrolytes with suspended cells, sCOD and OD600 were measured before and after the test. For sCOD measurement (Hach, 3-150 mg/L), an aliquot (10 or $20 \mathrm{~mL}$ ) of the suspension was vacuum filtered through a $0.45 \mu \mathrm{m}$ poly(ether sulfone) filter membrane (UltraSep, GVS Life Science); the residual filtrate after sCOD measurement was added back to the original suspension. The cell suspensions were also acid-digested before metal analysis. To recover any adsorbed lead, the used filter membrane was acid-digested (10 $\mathrm{mL} \mathrm{HNO}_{3}+10 \mathrm{~mL} \mathrm{HCl}+10 \mathrm{~mL}$ water, $150{ }^{\circ} \mathrm{C}$ for $30 \mathrm{~min}$ and topped with $\mathrm{HNO}_{3}$ and another $\left.30 \mathrm{~min}\right)$. The concentrations of lead were measured by ICP-MS. ${ }^{51}$ The complexation of dissolved lead and iron by different sEPS components was examined by SEC with ICP-MS detection; the detailed method can be found elsewhere. ${ }^{52}$ Information on peak identification is included in the Supporting Information (Figure S5).

To study localized corrosion in the presence of sEPS, galvanic tests were conducted in the same double-chamber electrochemical cell with the same kind of electrode at both ends. The experiment was run following these steps: deaeration, equilibrium current (i.e., zero current) collection for
$3 \mathrm{~h}$, disconnection, injection of a specified amount of sEPS/ cytochrome $\mathrm{c}$ stock solution to the control side (connected to the COM port), de-aeration of the control side, and current collection for another $3 \mathrm{~h}$. A half level of cytochrome $\mathrm{c}$ was used $(61.92 \mathrm{mg} / \mathrm{L})$. All electrodes were pretreated as described previously, and bicarbonate base electrolyte was used.

Preparation of $\boldsymbol{P}$. aeruginosa. $P$. aeruginosa was cultured for $10 \mathrm{~h}$ (until the cell density reached $10^{8} \mathrm{CFU} / \mathrm{mL}$ ) on a shaking incubator $\left(35^{\circ} \mathrm{C}, 175 \mathrm{rpm}\right)$ in tryptic soy broth $(3 \mathrm{~g} /$ $100 \mathrm{~mL}, 100 \mathrm{~mL})$ supplemented with yeast extract $(1.25 \mathrm{~g} / \mathrm{L})$. The cells were then pelleted by centrifugation $(3800 \mathrm{rpm}, 10$ $\mathrm{min}$ ), and the EPS were removed following an established method. $^{53}$ Details of EPS removal can be found in the Supporting Information. The cell numbers before and after a test run were quantified by OD600. Average cell density in the electrolyte at the beginning of the tests was $4 \times 10^{8} \mathrm{CFU} / \mathrm{mL}$ according to a correlation between the OD600 and the heterotrophic plate count.

\section{ASSOCIATED CONTENT}

\section{S Supporting Information}

The Supporting Information is available free of charge on the ACS Publications website at DOI: 10.1021/acsomega.8b02363.

Corrosion cell used in this study, interaction plots of ANOVA tests, redox potentials of anode and cathode at various conditions, a control test, and UV204 absorption spectrum for peak identification in SEC ICP-MS (PDF)

\section{AUTHOR INFORMATION}

\section{Corresponding Author}

*E-mail: graham.gagnon@dal.ca. Tel: 902494 3268. Fax: 902 4943108.

ORCID

Yaohuan Gao: 0000-0002-3251-436X

Benjamin F. Trueman: 0000-0002-1539-3092

Notes

The authors declare no competing financial interest.

\section{ACKNOWLEDGMENTS}

This work was funded by the Natural Sciences and Engineering Research Council (NSERC) Industrial Research Chair in Water Quality and Treatment [Grant number IRCPJ: 34983816]. The authors acknowledge the assistance from Heather Daurie and Dr Yuri Park at the Centre for Water Resources Studies.

\section{REFERENCES}

(1) Reuben, A.; Caspi, A.; Belsky, D. W.; Broadbent, J.; Harrington, H.; Sugden, K.; Houts, R. M.; Ramrakha, S.; Poulton, R.; Moffitt, T. E. Association of childhood blood-lead levels with cognitive function and socioeconomic status at age 38 years and with IQ change and socioeconomic mobility between childhood and adulthood. JAMA 2017, 317, 1244-1251.

(2) Lanphear, B. P.; Rauch, S.; Auinger, P.; Allen, R. W.; Hornung, R. W. Low-level lead exposure and mortality in US adults: a population-based cohort study. The Lancet Public Health 2018, 3, e177-e184.

(3) Bellinger, D. C. Lead Contamination in Flint - An Abject Failure to Protect Public Health. N. Engl. J. Med. 2016, 374, 11011103.

(4) (a) Edwards, M.; Triantafyllidou, S.; Best, D. Elevated Blood Lead in Young Children Due to Lead-Contaminated Drinking Water: 
Washington, DC, 2001-2004. Environ. Sci. Technol. 2009, 43, 16181623. (b) Hanna-Attisha, M.; LaChance, J.; Sadler, R. C.; Schnepp, A. C. Elevated Blood Lead Levels in Children Associated With the Flint Drinking Water Crisis: A Spatial Analysis of Risk and Public Health Response. Am. J. Public Health 2016, 106, 283-290. (c) Sanders, A. E.; Slade, G. D. Blood Lead Levels and Dental Caries in U.S. Children Who Do Not Drink Tap Water. Am. J. Prev. Med. 2018, 54, 157-163.

(5) Clark, B.; Masters, S. V.; Edwards, M. A. Lead Release to Drinking Water from Galvanized Steel Pipe Coatings. Environ. Eng. Sci. 2015, 32, 713-721.

(6) Edwards, M.; Dudi, A. role of chlorine and chloramine in corrosion of lead-bearing plumbing materials. J. - Am. Water Works Assoc. 2004, 96, 69-81.

(7) (a) Trueman, B. F.; Sweet, G. A.; Harding, M. D.; Estabrook, H.; Bishop, D. P.; Gagnon, G. A. Galvanic Corrosion of Lead by Iron (Oxyhydr)Oxides: Potential Impacts on Drinking Water Quality. Environ. Sci. Technol. 2017, 51, 6812-6820. (b) Deshommes, E.; Laroche, L.; Deveau, D.; Nour, S.; Prévost, M. Short- and Long-Term Lead Release after Partial Lead Service Line Replacements in a Metropolitan Water Distribution System. Environ. Sci. Technol. 2017, 51, 9507-9515. (c) Deshommes, E.; Trueman, B.; Douglas, I.; Huggins, D.; Laroche, L.; Swertfeger, J.; Spielmacher, A.; Gagnon, G. A.; Prévost, M. Lead Levels at the Tap and Consumer Exposure from Legacy and Recent Lead Service Line Replacements in Six Utilities. Environ. Sci. Technol. 2018, 52, 9451-9459.

(8) (a) Nguyen, C. K.; Stone, K. R.; Dudi, A.; Edwards, M. A. Corrosive Microenvironments at Lead Solder Surfaces Arising from Galvanic Corrosion with Copper Pipe. Environ. Sci. Technol. 2010, 44, 7076-7081. (b) Nguyen, C. K.; Stone, K. R.; Edwards, M. A. Nitrate accelerated corrosion of lead solder in potable water systems. Corros. Sci. 2011, 53, 1044-1049.

(9) DeSantis, M. K.; Triantafyllidou, S.; Schock, M. R.; Lytle, D. A. Mineralogical Evidence of Galvanic Corrosion in Drinking Water Lead Pipe Joints. Environ. Sci. Technol. 2018, 52, 3365-3374.

(10) (a) Trueman, B. F.; Gagnon, G. A. Understanding the Role of Particulate Iron in Lead Release to Drinking Water. Environ. Sci. Technol. 2016, 50, 9053-9060. (b) Clark, B.; Clair, J. S.; Edwards, M. Copper Deposition Corrosion Elevates Lead Release to Potable Water. J. - Am. Water Works Assoc. 2015, 107, E627-E637.

(11) McFadden, M.; Giani, R.; Kwan, P.; Reiber, S. H. Contributions to drinking water lead from galvanized iron corrosion scales. J. - Am. Water Works Assoc. 2011, 103, 76-89.

(12) Camara, E.; Montreuil, K. R.; Knowles, A. K.; Gagnon, G. A. Role of the water main in lead service line replacement: A utility case study. J. - Am. Water Works Assoc. 2013, 105, E423-E431.

(13) (a) Liu, H.; Gu, T.; Asif, M.; Zhang, G.; Liu, H. The corrosion behavior and mechanism of carbon steel induced by extracellular polymeric substances of iron-oxidizing bacteria. Corros. Sci. 2017, 114, 102-111. (b) Deutzmann, J. S.; Sahin, M.; Spormann, A. M. Extracellular Enzymes Facilitate Electron Uptake in Biocorrosion and Bioelectrosynthesis. mBio 2015, 6, No. e00496-15. (c) Jin, J.; Wu, G.; Guan, Y. Effect of bacterial communities on the formation of cast iron corrosion tubercles in reclaimed water. Water Res. 2015, 71, 207-218. (d) Enning, D.; Garrelfs, J. Corrosion of Iron by Sulfate-Reducing Bacteria: New Views of an Old Problem. Appl. Environ. Microbiol. 2014, 80, 1226-1236.

(14) (a) Keevil, C. W. The physico-chemistry of biofilm-mediated pitting corrosion of copper pipe supplying potable water. Water Sci. Technol. 2004, 49, 91-98. (b) Bremer, P. J.; Webster, B. J.; Wells, D. B. Biocorrosion of Copper in Potable Water. J. - Am. Water Works Assoc. 2001, 93, 82-91.

(15) (a) Zhang, Y.; Griffin, A.; Rahman, M.; Camper, A.; Baribeau, H.; Edwards, M. Lead Contamination of Potable Water Due to Nitrification. Environ. Sci. Technol. 2009, 43, 1890-1895. (b) White, C.; Tancos, M.; Lytle, D. A. Microbial Community Profile of a Lead Service Line Removed from a Drinking Water Distribution System. Appl. Environ. Microbiol. 2011, 77, 5557-5561.

(16) Kirmeyer, G. J.; Pierson, G.; Clement, J.; Sandvig, A.; Snoeyink, V.; Kriven, W.; Camper, A. Distribution System Water Quality Changes
Following Corrosion Control Strategies; AWWA Research Foundation and American Water Works Association: Denver, CO, 2000.

(17) Lau, H. Y.; Ashbolt, N. J. The role of biofilms and protozoa in Legionella pathogenesis: implications for drinking water. J. Appl. Microbiol. 2009, 107, 368-378.

(18) Schwake, D. O.; Garner, E.; Strom, O. R.; Pruden, A.; Edwards, M. A. Legionella DNA Markers in Tap Water Coincident with a Spike in Legionnaires' Disease in Flint, MI. Environ. Sci. Technol. Lett. 2016, $3,311-315$.

(19) (a) Teng, F.; Guan, Y. T.; Zhu, W. P. Effect of biofilm on cast iron pipe corrosion in drinking water distribution system: Corrosion scales characterization and microbial community structure investigation. Corros. Sci. 2008, 50, 2816-2823. (b) LeChevallier, M. W.; Lowry, C. D.; Lee, R. G.; Gibbon, D. L. Examining the Relationship Between Iron Corrosion and the Disinfection of Biofilm Bacteria. J. Am. Water Works Assoc. 1993, 85, 111-123.

(20) (a) Fish, K. E.; Collins, R.; Green, N. H.; Sharpe, R. L.; Douterelo, I.; Osborn, A. M.; Boxall, J. B. Characterisation of the Physical Composition and Microbial Community Structure of Biofilms within a Model Full-Scale Drinking Water Distribution System. PLoS One 2015, 10, No. e0115824. (b) Flemming, H.-C.; Wingender, J. The biofilm matrix. Nat. Rev. Microbiol. 2010, 8, 623633.

(21) Stadler, R.; Fuerbeth, W.; Harneit, K.; Grooters, M.; Woellbrink, M.; Sand, W. First evaluation of the applicability of microbial extracellular polymeric substances for corrosion protection of metal substrates. Electrochim. Acta 2008, 54, 91-99.

(22) (a) Roe, F. L.; Lewandowski, Z.; Funk, T. Simulating Microbiologically Influenced Corrosion by Depositing Extracellular Biopolymers on Mild Steel Surfaces. CORROSION 1996, 52, 744752. (b) Chan, K.-Y.; Xu, L.-C.; Fang, H. H. P. Anaerobic Electrochemical Corrosion of Mild Steel in the Presence of Extracellular Polymeric Substances Produced by a Culture Enriched in Sulfate-Reducing Bacteria. Environ. Sci. Technol. 2002, 36, 17201727. (c) Dong, Z. H.; Liu, T.; Liu, H. F. Influence of EPS isolated from thermophilic sulphate-reducing bacteria on carbon steel corrosion. Biofouling 2011, 27, 487-495.

(23) (a) Guibaud, G.; Comte, S.; Bordas, F.; Dupuy, S.; Baudu, M. Comparison of the complexation potential of extracellular polymeric substances (EPS), extracted from activated sludges and produced by pure bacteria strains, for cadmium, lead and nickel. Chemosphere 2005, 59, 629-38. (b) Bhaskar, P. V.; Bhosle, N. B. Bacterial extracellular polymeric substance (EPS): A carrier of heavy metals in the marine food-chain. Environ. Int. 2006, 32, 191-198.

(24) Kip, N.; van Veen, J. A. The dual role of microbes in corrosion. ISME J. 2015, 9, 542-551.

(25) Jin, J.; Wu, G.; Zhang, Z.; Guan, Y. Effect of extracellular polymeric substances on corrosion of cast iron in the reclaimed wastewater. Bioresour. Technol. 2014, 165, 162-165.

(26) (a) Stankovich, M. T.; Bard, A. J. The electrochemistry of proteins and related substances part III. Bovine serum albumin. $J$. Electroanal. Chem. Interfacial Electrochem. 1978, 86, 189-199. (b) Karimi, S.; Nickchi, T.; Alfantazi, A. Effects of bovine serum albumin on the corrosion behaviour of AISI $316 \mathrm{~L}, \mathrm{Co}-28 \mathrm{Cr}-6 \mathrm{Mo}$, and $\mathrm{Ti}-6 \mathrm{Al}-4 \mathrm{~V}$ alloys in phosphate buffered saline solutions. Corros. Sci. 2011, 53, 3262-3272.

(27) Cremers, C. M.; Jakob, U. Oxidant sensing by reversible disulfide bond formation. J. Biol. Chem. 2013, 288, 26489-26496.

(28) Arnold, R. B.; Edwards, M. Potential Reversal and the Effects of Flow Pattern on Galvanic Corrosion of Lead. Environ. Sci. Technol. 2012, 46, 10941-10947.

(29) (a) Sand, W.; Gehrke, T. Extracellular polymeric substances mediate bioleaching/biocorrosion via interfacial processes involving iron(III) ions and acidophilic bacteria. Res. Microbiol. 2006, 157, 4956. (b) Cao, B.; Ahmed, B.; Kennedy, D. W.; Wang, Z.; Shi, L.; Marshall, M. J.; Fredrickson, J. K.; Isern, N. G.; Majors, P. D.; Beyenal, H. Contribution of Extracellular Polymeric Substances from Shewanella sp. HRCR-1 Biofilms to U(VI) Immobilization. Environ. Sci. Technol. 2011, 45, 5483-5490. 
(30) (a) Manzella, M. P.; Reguera, G.; Kashefi, K. Extracellular Electron Transfer to $\mathrm{Fe}(\mathrm{III})$ Oxides by the Hyperthermophilic Archaeon Geoglobus ahangari via a Direct Contact Mechanism. Appl. Environ. Microbiol. 2013, 79, 4694-4700. (b) Boulay, N.; Edwards, M. Role of temperature, chlorine, and organic matter in copper corrosion by-product release in soft water. Water Res. 2001, 35, 683690.

(31) (a) Dinh, H. T.; Kuever, J.; Muszmann, M.; Hassel, A. W.; Stratmann, M.; Widdel, F. Iron corrosion by novel anaerobic microorganisms. Nature 2004, 427, 829-832. (b) Enning, D.; Venzlaff, H.; Garrelfs, J.; Dinh, H. T.; Meyer, V.; Mayrhofer, K.; Hassel, A. W.; Stratmann, M.; Widdel, F. Marine sulfate-reducing bacteria cause serious corrosion of iron under electroconductive biogenic mineral crust. Environ. Microbiol. 2012, 14, 1772-1787. (c) Venzlaff, H.; Enning, D.; Srinivasan, J.; Mayrhofer, K. J. J.; Hassel, A. W.; Widdel, F.; Stratmann, M. Accelerated cathodic reaction in microbial corrosion of iron due to direct electron uptake by sulfatereducing bacteria. Corros. Sci. 2013, 66, 88-96.

(32) (a) Guanglai, L.; et al. Surface contact stimulates the just-intime deployment of bacterial adhesins. Mol. Microbiol. 2012, 83, 4151. (b) van Loosdrecht, M. C. M.; Lyklema, J.; Norde, W.; Zehnder, A. J. B. Bacterial adhesion: A physicochemical approach. Microb. Ecol. 1989, 17, 1-15.

(33) Klausen, M.; Heydorn, A.; Ragas, P.; Lambertsen, L.; AaesJorgensen, A.; Molin, S.; Tolker-Nielsen, T. Biofilm formation by Pseudomonas aeruginosa wild type, flagella and type IV pili mutants. Mol. Microbiol. 2003, 48, 1511.

(34) Keresztes, Z.; Felhősi, I.; Kálmán, E. Role of redox properties of biofilms in corrosion processes. Electrochim. Acta 2001, 46, 38413849.

(35) (a) Marsili, E.; Baron, D. B.; Shikhare, I. D.; Coursolle, D.; Gralnick, J. A.; Bond, D. R. Shewanella secretes flavins that mediate extracellular electron transfer. Proc. Natl. Acad. Sci. U.S.A. 2008, 105, 3968-3973. (b) Okamoto, A.; Saito, K.; Inoue, K.; Nealson, K. H.; Hashimoto, K.; Nakamura, R. Uptake of self-secreted flavins as bound cofactors for extracellular electron transfer in Geobacter species. Energy Environ. Sci. 2014, 7, 1357-1361.

(36) Richter, K.; Schicklberger, M.; Gescher, J. Dissimilatory Reduction of Extracellular Electron Acceptors in Anaerobic Respiration. Appl. Environ. Microbiol. 2012, 78, 913-921.

(37) Schock, M. R.; Hyland, R. N.; Welch, M. M. Occurrence of Contaminant Accumulation in Lead Pipe Scales from Domestic Drinking-Water Distribution Systems. Environ. Sci. Technol. 2008, 42, 4285-4291.

(38) (a) Kato, S.; Yumoto, I.; Kamagata, Y. Isolation of Acetogenic Bacteria That Induce Biocorrosion by Utilizing Metallic Iron as the Sole Electron Donor. Appl. Environ. Microbiol. 2015, 81, 67-73. (b) Ishii, T.; Kawaichi, S.; Nakagawa, H.; Hashimoto, K.; Nakamura, R. From chemolithoautotrophs to electrolithoautotrophs: $\mathrm{CO} 2$ fixation by $\mathrm{Fe}(\mathrm{II})$-oxidizing bacteria coupled with direct uptake of electrons from solid electron sources. Front. Microbiol. 2015, 6, No. 994.

(39) Lovley, D. R. Electromicrobiology. Annu. Rev. Microbiol. 2012, 66, 391-409.

(40) Liu, Y.; Bond, D. R. Long-distance electron transfer by G. sulfurreducens biofilms results in accumulation of reduced c-type cytochromes. ChemSusChem 2012, 5, 1047-1053.

(41) Shi, L.; Squier, T. C.; Zachara, J. M.; Fredrickson, J. K. Respiration of metal (hydr)oxides by Shewanella and Geobacter: a key role for multihaem c-type cytochromes. Mol. Microbiol. 2007, 65, $12-20$.

(42) Beese-Vasbender, P. F.; Nayak, S.; Erbe, A.; Stratmann, M.; Mayrhofer, K. J. J. Electrochemical characterization of direct electron uptake in electrical microbially influenced corrosion of iron by the lithoautotrophic SRB Desulfopila corrodens strain IS4. Electrochim. Acta 2015, 167, 321-329.

(43) Fish, K. E.; Osborn, A. M.; Boxall, J. Characterising and understanding the impact of microbial biofilms and the extracellular polymeric substance (EPS) matrix in drinking water distribution systems. Environ. Sci.: Water Res. Technol. 2016, 2, 614-630.

(44) Li, J.; Wang, W.; Moe, B.; Wang, H.; Li, X.-F. Chemical and Toxicological Characterization of Halobenzoquinones, an Emerging Class of Disinfection Byproducts. Chem. Res. Toxicol. 2015, 28, 306318.

(45) DeSantis, M. K.; Schock, M. R.; Bennett-Stamper, C. L. In Incorporation of Phosphate into Destabilized $\mathrm{PbO}_{2}$ Pipe Scales, AWWA Water Quality Technology Conference Toronto, ON, Canada, 2012.

(46) Beech, I. B.; Sunner, J. Biocorrosion: towards understanding interactions between biofilms and metals. Curr. Opin. Biotechnol. 2004, 15, 181-186.

(47) Wagner, D.; Chamberlain, A. H. L. Microbiologically influenced copper corrosion in potable water with emphasis on practical relevance. Biodegradation 1997, 8, 177-187.

(48) Malvankar, N. S.; Tuominen, M. T.; Lovley, D. R. Lack of cytochrome involvement in long-range electron transport through conductive biofilms and nanowires of Geobacter sulfurreducens. Energy Environ. Sci. 2012, 5, 8651-8659.

(49) Monazam, E. R.; Breault, R. W.; Siriwardane, R. Kinetics of Magnetite (Fe3O4) Oxidation to Hematite (Fe2O3) in Air for Chemical Looping Combustion. Ind. Eng. Chem. Res. 2014, 53, 13320-13328.

(50) Revie, W. R.; Uhlig, H. H. Corrosion and Corrosion Control: An Introduction to Corrosion Science and Engineering, 4th ed.; John Wiley \& Sons, Inc.: New Jersey, 2008; pp 445-448.

(51) American Public Health Association, A. W. A. Water Pollution Control Federation, Standard Methods For the Examination of Water and Wastewater, 22nd ed.; American Public Heath Association: Washington, DC, 2012.

(52) Trueman, B. F.; Gagnon, G. A. A new analytical approach to understanding nanoscale lead-iron interactions in drinking water distribution systems. J. Hazard. Mater. 2016, 311, 151-157.

(53) Keithley, S. E.; Kirisits, M. J. An improved protocol for extracting extracellular polymeric substances from granular filter media. Water Res. 2018, 129, 419-427. 